\title{
Atypical Forms of Employment as a Determinant of Economic Activity of People above 45 Years Old
}

\begin{abstract}
:
Taking into consideration established directions of strategic actions and the need to exploit enterprises of custom employment statuses in practice, we would like to examine the alternative in the more detailed way above the vocational activation of people over 45 years old with the temporary work. The purpose of the study formulated in this way allows validating the research hypothesis which is: the temporary work doesn't constitute the important instrument of supporting the occupational activity of people who are 45 years old. Above all features the shown population will be a base of conducted deliberations, a tendency to work in custom employment statuses and scale of exploiting this form of the occupational activity in Poland.
\end{abstract}

Key words: temporary work, occupational activity, people above 45 years old, determinant of the occupational activity.

\section{Introduction}

The situation of people over 45 years old on the labour market is difficult. As demonstrated by research carried out for the project "Studying the impact of flexible forms of employment and work organization on labour force aged 45+”, their economic activity is low [Sobocka- Szczapa (ed.), Poliwczak 2011]. In addition, this population is characterized by a high unemployment and too early inaction and marginalization, which is mainly a consequence of demographic change and the legal conditions (early possibility of collecting retirement benefits) [Spytek-Bandurska]. At the same time, the chances of this population to 
find employment decline with time, because such people are less competitive in comparison with younger categories of workers. This is a factor whose importance is increasing especially in the situation of decreasing number of work places and reduced tendency of employers to offer jobs. Also, do not forget about the historical and cultural factor that exerts a considerable influence on the activity and entrepreneurial communities and other elements of social and economic life, determining the development of new forms of employment in Poland. Atypical forms of employment are associated with the flexibility of the labor market. They are seen as important factors in the harmonious development of the economy and its actors, which is particularly important now, in the era of globalization. To function effectively, enterprise need to make decisions quickly, even in the area of employment (increase or decrease the number of employees, change forms of employment, the organization of working time, the skills of workers to meet the current needs). In particular, these actions relate to the elderly, because employers are afraid of not fulfilling their expectations.

These determinants affect the need to find solutions that would enable extension of professional activity for the labour resources aged 45+, as well as increase this activity. This could result in the increase of management's effectiveness of the economic units that in the nearest future may face the barrier of limited access to the resources of young people and school leavers that are entering the labour market. It seems necessary also from the point of view of the Europe 2020 Strategy [Komunikat, 2010] and of, developed on this basis, the National Development Strategy 2020 [Strategia, 2012]. These documents assume that one of the changes' directions will be a growth, which is promoting a social inclusion. It means supporting a high-employment economy, which also delivers economic, social and territorial cohesion and the necessity for operating in the field of social inclusion, involving an increase of the professional activity of people excluded or at risk of social exclusion ${ }^{1}$.

Taking into consideration the expected directions of strategic actions and the necessity for using the non-standard forms of employment in the enterprises' practice, which happens more often, we would like to look in more detail at the possibilities of professional activation of people above 45 years old in the form of temporary employment ${ }^{2}$. Expressed in this way, the objective of the elaboration allows to verify the research hypothesis, that is: atypical forms

1 Cf. Priorities and areas indicated in those documents.

2 Temporary work is a form of non-standard employment, which is part of flexicurity. For this model consists of four pillars fact: flexible and reliable contractual arrangements, strategies for learning throughout life, active labor market policies and modern social security systems. 
of employment, including temporary work, are known - both employers and workers - to forms of employment, the use of which is not common, due to the limited confidence in these forms, especially representatives of the supply side of the labor market. The basis for the conducted considerations will be primarily features of this population, its tendency to work in non-standard forms of employment and the scale of the current utilization of this form of economic activity in Poland.

\section{Characteristics of people over 45 years old and the temporary employ- ment}

Labour resources over the age of 45 have a steadily reducing capacity and physical and mental condition, which applies especially to their late maturity [Rysz-Kowalczyk 1996, pp. 4 -50]. Risk areas affecting the professional activity can be subdivided (Figure 1). It should also be noted that, depending on many complex factors, both internal (skills, health, value system) and external (employment policy, legislation, local environment, family), this period may be delayed [Bugajska 2008, pp. 5-7, Sobocka-Szczapa 2007; Klimkiewicz 2009].

Figure 1. The factors limiting professional activity of people $45+$

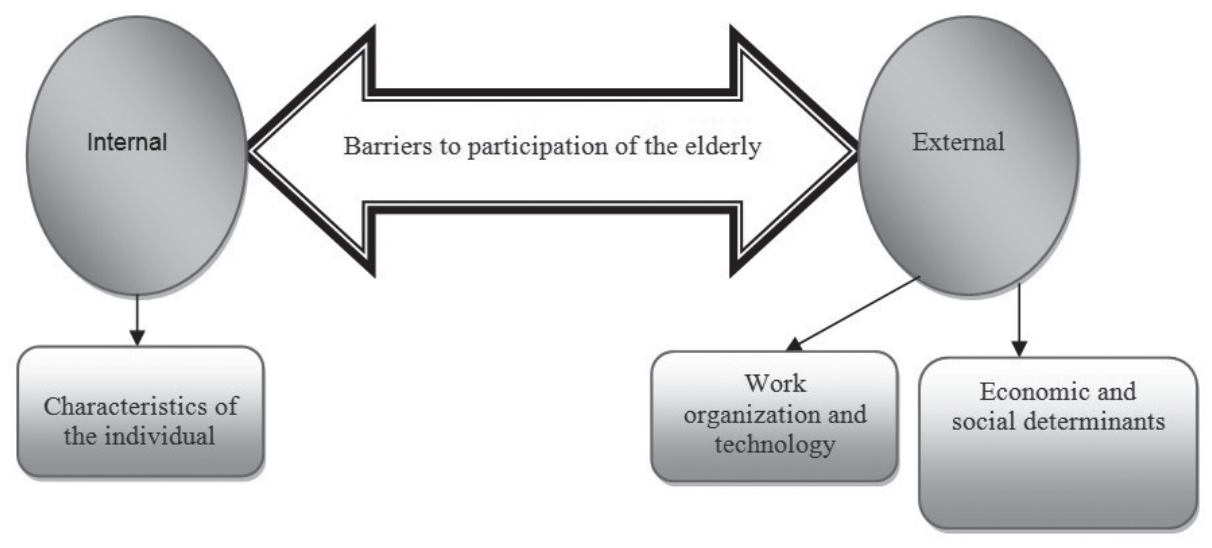

Source: own.

The determinants that are limiting the employment of older people, also belonging to the group of units features, include: relatively low level of education, poor health, tiredness of work, difficulties in adapting to the new conditions, fear of competition from the young people. The second group, related to the organization of work and technology, are features including the necessity of acquiring new skills and qualifications, lack of appropriate training for 
workers and excessive pace of work. The third group - the economic and social conditions - creates the situation on the labour market, mainly unemployment, age discrimination, the needs of families for work of aging people and the pension schemes that encourage the relatively early end of professional careers. An important factor is also the attitude of employers, on which depends the preservation of jobs for the elderly. If they are guided by stereotypes, that the occupational usefulness and mobility of workers over 45 years are small, the chances for remaining in employment for this category decline. It is generally believed that such workers need to spend more time and effort to effectively carry out their duties [Makowic-Dąbrowska, Bugajska 2006].

Looking at the above-mentioned groups of factors that fundamentally shape the competitive position of those over 45 years in the labour market, as well as affect the level and scale of their professional activity, it should be emphasized that:

- from the point of view of the individual's characteristics, the biggest limitation may be offering jobs on production, requiring high efficiency and strength,

- significant barrier for professional activity are weaker motivation and lack of aspiration due to a decrease of energy, worse performance of stimulation mechanisms and increase of stressors [Spytek-Badurska], that cause accumulation of difficulties in the assimilation of knowledge and reduces the ability to remember the obtained information and acceptance changes, in particular the technical and organizational,

- older people require increased scope of assistance or incentives for undertaking new ventures; this is particularly true for those who are at the mental stage of waiting for retirement [Hrynkiewicz 2012],

- fulfilling other social roles means that there are different issues and responsibilities, mainly as a result of changes occurring in the external and family environment (e.g. empowerment of children, birth of grandchildren, death of parents), that contribute to the treatment of professional matters as secondary,

- the financial considerations are of considerable importance, that favor earlier deactivation; incentive to discontinue the work is in fact the fixed pension, which guarantees the social security, as well as the opportunity to take an additional employment, often in the "gray zone", resulting in higher incomes in comparison to previous earnings.

In comparison to the factors listed above, that affect the reduction of professional activity of people 45+, their biggest advantages are the possessed knowledge and professional experience, that creates the conditions for using this la- 
bour resources in the companies' actions in the positions, that are deprived of such risks. This could contribute to the improvement of work quality and its organization. Such competitive advantages of older workers may just be the subject of the offer, implemented through temporary employment agencies. In order to increase the professional activity of people aged $45+$, there are also needed: a systemic solution - namely, the change in the pension system, health care and social benefits, as well as the promotion of flexible forms of employment, improvement of possibilities of undertaking and continuing various classes, providing optimal work conditions, implementation of innovative processes, prevention of discriminatory behavior, increase of work abilities and encourage the lifelong learning. By doing so, for the delivery of sustainable, long-term prevention strategies against early withdrawal from the labour market, one can in fact increase the social productivity and commitment of older workers in the building of the general welfare, as well as reduce the perception of the group as beneficiaries, aggravating the state budget. If such support becomes a priority of many entities (e.g. public employment services, social welfare units), one can expect measurable results in the form of elimination of passive attitudes, increase mobility and the lower side effects of being out of work and livelihoods. It is also important to support employers in creating or maintaining jobs, matched to the abilities and predispositions of older people. A major role in this area can play the promotion among the demand-side representatives of non-standard forms of employment (including temporary work), as well as building ties between the generations, based on mutual understanding and respect that create the possibility of using in the activities of companies the so-called ,jobcoaching”, as a way to combine extensive knowledge and experience with the knowledge, skills and physical fitness of young people. This type of behavior is important, for instance, to reduce of the digital exclusion, which we have to deal among the older group both employees and job applicants [Kryńska, Arendt (ed.) 2010 Sobocka-Szczapa (ed.) 2011]. One can then expect the opinion that the professional activity of the elderly people is limited due to the employment of young people will be less important [Bałandynowicz-Panfil 2009, p. 16].

\section{The tendency of people aged $\mathbf{4 5}+$ to work in non-standard forms}

In 2012, for the project „Studying the impact of flexible employment and work organization in the professional activity of the labour force aged 45 +", researches have been done among people over 45 years old, in which the subjects of researchers' interest were issues related to the tendency of labour resources for employment in atypical forms [Kryńska (ed.) 2012]. The studies 
involved groups: employed, unemployed, economically inactive people (600 people) and employers (200), because the basic assumption of the project was the existence of a causal link between the use of the flexible (non-standard) forms of employment and work organization by the business entities and the level of professional activity of people at the age of 45 and more years. Selection of respondents had a representative character. The method used in the study were interview questionnaires in which were included blocks of questions related to the acceptance of non-standard forms of employment by the people in senior years of working ages, both in the working age, as well as after its completion.

As is clear from the studies, workers with more than 45 years, the least likely of all studied groups, were willing to take employment in non-standard forms, although a substantial share were characterized by those to whom such an offer was ever made. More willing - compared to this category of labour resources - were in this matter unemployed, although it is strictly connected with the lack of other offers. In the case of economically inactive was similar, because taking such employment contributes to remain longer in employment.

The main factors which favored the acceptance were the economic considerations. It was a determinant, which did not play such an important role in the case of other members of the supply side of the labour market. The dominant reason for such a decision among the unemployed was the situation on the labour market and the lack of others, more favorable job offers. This reason is also held in the opinions of the economically inactive, although undoubtedly important was also a health status. Less important, despite of the colloquial opinion in this field, was family situation.

Representatives of the demand side of the labour market, for obvious reasons, had different opinions about the opportunities associated with the use of non-standard forms of employment. First of all, a considerable frequency of this method of employees' employment occured. The main reason was the economic situation (costs reduction), the need for seasonal work, as well as changes in employment needs, related to changes in market demand.

There were no appreciable differences in the opinions of respondents associated with the preferred type of atypical forms of employment. First of all, it was a part-time job and in the next stage - based on a civil law contract (contract to perform a specified task, order contract). Small number of respondents felt that it could work in the form of temporary employment, and being professionally active through a temporary employment agency. This reflects the limited - so far - importance of this form in framing the professional activity of labor resources in the studied age categories. These results are con- 
sistent with analyzes of the demand side of the labour market. In the Polish enterprises the civil law contracts and fixed-term employment are the most commonly used atypical forms of employment [Arendt, Kukulak-Dolata, Poliwczak 2009, pp. 135-198, Kukulak-Dolata, Arendt 2010, pp. 61-82].

In general, the study shows that much smaller - at least declaratively - are the barriers to use the atypical forms of employment among the representatives of the demand side of labour market. Labour resources, despite the different reasons that make the professional activation possible in such forms, actually take smaller part in this kind of employment. At the same time of making such a decision, almost nobody connected it with the ability to implement it in the context of temporary work. These opinions do not fundamentally differentiate between employed, unemployed, economically inactive, as well as employers. This may mean that despite the long functioning of that atypical form of employment, the scale of using it is limited. This may be also a derivative of the very rare use of contracts to perform a certain task in practice by the Polish companies. The extension of this method of employment, resulting from the flexibility of working time, could be an indicator for the increased interest in functioning of the employment agencies, including temporary employment agencies, of both employers and representatives of labour.

\section{Operation scale of work agencies offering temporary employment}

The role of temporary work increases among the non-standard forms of employment [Czapliński 2010]. It is recognized that this is promoted by the contemporary economic and social processes, characterized by a high dynamics of changes, as well as significant unpredictability. Temporary work can thus become in Poland, next to the job placement (domestic and foreign), the most important activity of the employment agencies. In fact, the company may achieve a significant competitive advantage by offsetting, at least in part, the risk that arises from the functioning on the market with high volatility of the current and future demand [Gołuchowski 2005, Papińska-Kacperek 2008, Ciesielski 2009]. Therefore, it must be assumed that the process of flexible adaptation of the size and form of employment to the changing market needs will progress. This will force fast, simple and cheap procedures to make and resolve employment relationship. It can also impact the distribution of employees at those who form the core of the company (strategic employees) and those who will do the work of an ad-hoc basis, in the task, part-time work. Therefore, as stated by A. Patulski [Patulski 2008], the institution of temporary work increasingly becomes the only solution to the situation of the permanent shortage of staff and temporary demand increase for workers in 
the enterprise. These reasons cause the fact that temporary employment can become one of the basic forms of professional activation for people in senior years of working ages, and thus play an important role in extending professional life of this group.

Let's look at the scale of temporary employment agencies.

At the end of 2008 there were 2,166 temporary employment agencies registered in the country, that represent $56.8 \%$ of all employment agencies (3811) [Rozporządzenie 2005]. Throughout this year, they sent to such work 474747 people. With this 214750 (45\%) were employed in agencies on a contract of employment for a fixed term and temporary employment. In contrast, $55 \%$, or 259997 people who are not employees of the Agency, have been directed to work under a contract of civil law. In 2009, there was a greater decrease of referrals to work (over 20\%). In subsequent years (2010 and 2011) there was noted a systematic increase in the number of people sent to work temporarily. It was, respectively, 433102 people and 499024 people [Agencje 2009, Agencje 2011].

Among those targeted by temporary employment agencies to employers in 2009, the majority were women (50.7\%, i.e. 219644 people). But it was a small advantage, testifying to the presence of the same opportunities to find a job, regardless of gender. In contrast, quite a significant variation occurs in the case of respective age groups. For people over 50 years of age, sent to work temporarily, in general numbers they accounted for only 6.9\% (29 706 people). There was also few employers who have used the services of such agencies (slightly more than 10 thousand) [Agencje 2009].

There was also a large spatial differentiation of the effective actions taken by the agencies. In the same year, in comparison with other voivodships, the greatest achievements in this field had agencies of Mazowieckie, Dolnośląskie and Łódź. Number of temporary employees performing work developed in these regions at the level of 143484 people, 75802 people and 50656 people. Therefore, the share of temporary workers in these agencies amounted in total to $62.3 \%$. In contrast, few people have taken temporary work in Świętokrzyskie (199 people) and Podlaskie (326 people). The spatial structure of number of employees was strongly correlated with the number of employers using such services. In this case, they were, first and foremost employers of the same regions, and their share in the total number of employers - members amounted to $58.8 \%$. It is worth emphasizing that significant and comparable to those regions was the number of employers, who hired temporary workers, located in the voivodship of Silesia (1 027). The least such entities functioned in Świętokrzyskie (19), Podlaskie (31), Warmińsko-Mazurskie (42) and Podkarpackie (59). 
The most common form of employment was working for a short period, i.e. up to three months. For this kind of work has been directed $58 \%$ of temporary workers $(251471)$. Temporary work over the one year was provided by only 22378 people. At the same time the largest group of people assigned to temporary work were unskilled workers in the industry (64 552 persons) and storekeepers (48 184 people). In this case there was differentiation by gender, because among both women and men dominated these two professions.

\section{Summary}

Atypical forms of employment - according to research - are potentially a tool that improves the employment opportunities of people that are in a special situation on the market - young people, older people, people caring for family members, single parents, etc. These forms can also significantly contribute to the extension activity of people above 45 years of age. Ability for departing from the standard employment allows such people to stay on the labour market, because it would not be possible for them, from various reasons, to meet the standard employment requirements. At the same time, employment in non-standard forms, according to the concept of flexicurity should guarantee security, understood not as confidence of maintaining current job, but as a job security - the ability to transition from one job to another, and from unemployment to employment. However, the most concerns occur in the area of atypical forms of employment security. Following the publication of the Raport Młodzi 2011 [Młodzi 2011] in the jargon of the media appeared a term "junk contracts", which is also in scientific research ${ }^{3}$. Moreover, more and more questions arise whether the development of atypical forms of employment does not lead to segmentation, or even to dualisation of labour market, in which there are first and second category $y^{4}$.

Emphasized in the development of temporary work balance for activation of persons aged $45+$ can also be related to a number of benefits of this form of employment, which would include [Bąk 2006, Pisarczyk 2006]:

3 According to M. Bednarski and K.W. Frieske, the phenomenon of academic jargon, is described as a "pluralism of institutional forms of work" [Bednarski 2012, Frieske 2012].

4 People employed in the standard forms included in the so-called the primary segment of the labor market, which is characterized by relatively stable employment, have better prospects for career development and the relatively higher security. While those working in atypical forms go to the secondary segment of the labor market, characterized by a greater fluctuation of employees, worse working conditions and career prospects and a lower wage. 
- abolition of working time, place and ways of working rigor,

- usefulness in updating the knowledge and skills, resulting from the return to work or gaining initial professional experience,

- lowering the costs of employers while hiring a worker (relief for personel service),

- reducing the risk of employment incorrect worker (employee of little use for the company).

Therefore, an effort should be taken in the direction of spreading primarily this form of employment, which mainly for people over 45 years, may contribute to the formation of the diffusion effect of information and transfer of experience. Temporary job creates the chances of conflict-free transition to the professional activity of people over 45 years, even taking into account that it can be regarded as a transitional way of earning, not a target model career [Spytek-Bandurska, Szylko-Skoczny 2008]. It is worth mentioning here that existing legislation creates a sufficient number of solutions that facilitate professional activation of such people. Therefore, the main obstacle to the implementation of actions that affect bigger interest in temporary employment and other atypical forms of employment, as a tool for professional mobilizing of people aged over 45 years, may be more likely the ignorance and stereotypes than the lack of a suitable legal instruments.

\section{Bibliography}

Agencje Zatrudnienia 2008 r. (2009), Ministerstwo Pracy i Polityki Społecznej. Departament Rynku Pracy, Warszawa.

Agencje zatrudnienia 2010 r. (2011), Ministerstwo Pracy i Polityki Społecznej Departament Rynku Pracy, Warszawa.

Arendt Ł., Kukulak-Dolata I., Poliwczak I. (2009), Perspektywy implementacji modelu flexicurity na poziomie przedsiębiorstw [in:] E. Kryńska (ed.), Flexicurity w Polsce. Diagnoza i rekomendacje, Ministerstwo Pracy i Polityki Społecznej, Departament Rynku Pracy, Warszawa.

Bałandynowicz-Panfil K. (2009), Źródta dyskryminacji osób starszych na rynku pracy [in:] Równi na rynku pracy? Analiza sytuacji absolwentów i osób w wieku 50+ w województwie pomorskim, ed. J. Fryc, Wyższa Szkoła Bankowa w Gdańsku, Gdańsk.

Bąk E. (2006), Elastyczne formy zatrudnienia, Warszawa.

Bednarski M. (2012) Koszty i korzyści zatrudnienia na czas określony, „Polityka Społeczna”, nr 9.

Bugajska J. (2006), Gtos osób starszych, sita przysztości, Forum 50+ Seniorzy XXI wieku, Warszawa. 
Bugajska J. (2007), Pracownicy starsi - możliwości i uwarunkowania fizyczne, Warszawa.

Ciesielski M. (2009), Instrumenty zarządzania tańcuchami dostaw, Warszawa.

Czapliński P. (2010), Praca tymczasowa $w$ dziatalności agencji zatrudnienia (ujęcie regionalne), Akademia Pomorska, „Słupskie Prace Geograficzne”, nr 7, Słupsk.

Frieske K.W. (2012), Dynamika polskiego rynku pracy: modernizacja czy zależnośc, „Polityka Społeczna” nr 9.

Gołuchowski J. (2005), Technologie informacyjne w zarządzaniu wiedza, Katowice. Hrynkiewicz J. (red.) (2012), O sytuacji ludzi starszych, Rządowa Rada Ludnościowa, Warszawa.

Klimkiewicz A. (2009), Spoteczno-prawne uwarunkowania aktywności zawodowej osób w wieku 50+ na rynku pracy, „Polityka Społeczna”, nr 2.

Komunikat Komisji. EUROPA 2020. Strategia na rzecz inteligentnego i zrównoważonego rozwoju sprzyjającego wtączeniu spotecznemu (2010), Komisja Europejska, $\operatorname{KOM}(2010) 2020$ wersja ostateczna, Bruksela.

Kowaleski J., Szukalski P. (red.) (2006), Nasze starzejące się spoteczeństwo. Nadzieje i zagrożenia, Łódź.

Kryńska E., Arendt Ł. (red.) (2010), Wykluczenie cyfrowe na rynku pracy, IPiSS, Warszawa.

Kryńska E. (red.) (2012), Badanie wptywu elastycznych form zatrudnienia i organizacji pracy na aktywność zawodowa zasobów pracy w wieku 45+. Raport syntetyczny, IPiSS, Warszawa (maszynopis).

Kukulak-Dolata I., Arendt Ł. (2010), Flexicurity w praktyce - ujęcie mikroekonomiczne [w:] A. Tomanek (red.), Flexicurity jak recepta na wyzwania wspótczesnego rynku pracy, Izba Rzemieślnicza i Przedsiębiorczości w Białymstoku, Białystok.

Makowic-Dąbrowska, T., Bugajska, J., (2006), Czynniki zawodowe przedwczesnego obniżenia zdolności do pracy u osób starszych, „Bezpieczeństwo Pracy” nr 2.

Mtodzi 2011 (2011), Kancelaria Prezesa Rady Ministrów, Warszawa.

Papińska-Kacperek J. (2008), Spoteczeństwo informacyjne, Warszawa.

Patulski A. (2008), Nietypowe formy zatrudnienia. Elastyczność czy stabilizacja?, cz. 2, „Monitor Prawa Pracy” nr 3.

Pisarczyk Ł. (2006), Terminowe umowy o prace — szansa czy zagrożenie?, „Praca i Zabezpieczenie Społeczne" nr 8.

Rozporządzenie Ministra Gospodarki i Pracy z dnia 13 października 2005 r. w sprawie wpisu do rejestru podmiotów prowadzących agencje zatrudnienia oraz informacji składanych przez agencje zatrudnienia (Dz. U. nr 212, poz. 1770). 
Rysz-Kowalczyk B. (1996), Pokolenie w fazie późnej dojrzatości. Deformacje cyklu życia a zagrożenia spoteczne we wspótczesnej Polsce, Warszawa.

Sobocka-Szczapa H. (red.) (2011), Wykluczenie cyfrowe na Mazowszu. Wyniki badań, IPiSS, Warszawa.

Sobocka-Szczapa H. (red.), Poliwczak I. (2011), Diagnoza sytuacji osób w wieku $45+$ na rynku pracy $w$ Polsce i wybranych krajach Unii Europejskiej, IPiSS. Warszawa (maszynopis).

Sobocka-Szczapa H. (2012), Zasoby pracy w wieku 45+ na rynku pracy $w$ Polsce, „Polityka Społeczna”, nr 8.

Spytek-Bandurska G., Aktywizacja zawodowa osób w fazie późnej dojrzatości i starszych $w$ Polsce, http://recesja.icm.edu.pl/ips/problemyps/pps17/PPS17-Spytek-Bandurska.pdf [dostęp 15.07.2013].

Spytek-Bandurska G., Szylko-Skoczny M. (2008), Praca tymczasowa. Szanse i zagrożenia, Warszawa.

Strategia Rozwoju Kraju 2020 (2012), MRR, Warszawa. 